\title{
A Lacewing Bug, Paleoanomala aptenus gen. et sp. nov. (Hemiptera: Tingidae), in Mid-Cretaceous Burmese Amber
}

\author{
George Poinar, Jr. ${ }^{a}$; Fernando E. Vega ${ }^{\text {b* }}$ (D) \\ aDepartment of Integrative Biology, Oregon State University, Corvallis, OR, 97331, U.S.A. Email: \\ poinarg@science.oregonstate.edu \\ ${ }^{b}$ Sustainable Perennial Crops Laboratory, U. S. Department of Agriculture, Agricultural Research Service, \\ Beltsville, MD, 20705, U.S.A. \\ *Corresponding author: Fernando.Vega@usda.gov \\ (C) The Author(s) 2020
}

\section{ABSTRACT}

A female lacewing bug in mid-Cretaceous Burmese amber is described as Paleoanomala aptenus gen. et sp. nov. (Tingidae: Hemiptera). This specimen is small and flightless and has partially fused hemelytra. The dorsum is covered with areoles formed by large dark punctures. The reduced eyes, lack of ocelli, and a flattened body suggest that this specimen lived in a stable, protected habitat. It is proposed that the precursor of Paleoanomala was macropterous with functional wings, however, the suture separating the original hemelytra is now partially fused and not capable of separation.

\section{ARTICLE HISTORY}

Received 13 May 2020

Revised 20 May 2020

Accepted 1 June 2020

KEYWORDS
Burmese amber
Hemiptera
Lacewing
Mid-Cretaceous amber
Myanmar
Tingidae

\section{Introduction}

Lace or lacewing bugs (Hemiptera: Tingidae) are an ancient cosmopolitan group with a wide range of morphological shapes and feeding sites. They are herbivores and most are free-living and feed on the foliage of angiosperms, both dicots and monocots. Some are found in flower galls where they feed on pollen while others are subterranean and feed on the roots of angiosperms. Many species are host specific, feeding on a single species or genus of plants and when populations build up, plant damage can result. While damage to crops and flowers is not frequently noted, some tingids have been used as biological control agents of weeds. For example, Teleonemia scrupulosa Stål, the lantana lace bug, was introduced from Central America, via Fiji, to Australia to control lantana (Gross \& Cassis, 1991). Species of Acalypta Westwood (Fig. 1) develop on mosses and are capable of delivering a painful "sting" when removed from leaves of Racomitrium sp. (Poinar, 2019). All extant flightless members of the family Vianaididae (Tingoidea) appear to be myrmecophilous inquilines, even though they are phytophagous (Comstock, 1950; Schuh \& Slater, 1995). The 
specimen described below is the first fossil flightless member of the Tingoidea.

\section{Materials and methods}

The specimen originated from the Noije Bum 2001 Summit Site mine excavated in the Hukawng Valley in 2001 and located southwest of Maingkhwan in Kachin State $\left(26^{\circ} 20^{\prime} \mathrm{N}\right.$, 96 $6^{\circ} 36^{\prime} \mathrm{E}$ ) in Myanmar. Based on paleontological evidence this site was dated to the late Albian of the Early Cretaceous (Cruickshank \& Ko, 2003), placing the age at 97 to 110 Mya. A more recent study using $\mathrm{U}-\mathrm{Pb}$ zircon dating determined the age to be $98.79 \pm 0.62$ Mya or at the Albian/Cenomanian boundary (Shi et al., 2012). Nuclear magnetic resonance (NMR) spectra and the presence of araucaroid wood fibers in amber samples from the Noije Bum 2001 Summit Site indicate an araucarian tree source for the amber (Poinar et al., 2007). Observations and photographs were made with a Nikon SMZ-10 R stereoscopic microscope and Nikon Optiphot compound microscope with magnifications up to $800 \mathrm{X}$.

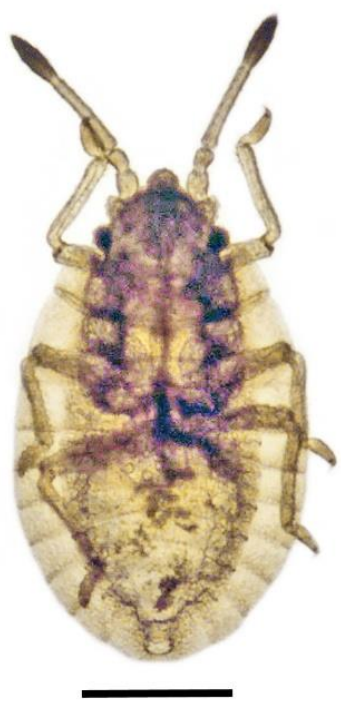

Fig. 1. Extant nymph of Acalypta sp. recovered from a moss (Racomitrium sp.) in Oregon. Scale bar $=0.8 \mathrm{~mm}$ (Photo by G. O. Poinar, Jr.).

\section{Results}

Order Hemiptera

Superfamily Tingoidea Laporte, 1833
Family Tingidae Laporte, 1833

Subfamily Tingiometrinae Heiss, Golub \& Popov, 2000 (extinct)

Genus Paleoanomala gen. n.

LSID: urn:lsid:zoobank.org:pub:58EB69C1C9BA-4B2D-972A-C4EF7830FA2C

Diagnosis: Flightless female with fused hemelytra; body small, dorsum punctate, with areoles outlined by large dark punctures; eyes reduced, ocelli absent; head somewhat elongated, antelocular portion slightly longer than postocular portion; clypeus swollen and rounded at tip; labium 4-segmented, its apex reaching posterior margin of middle coxa; dorsum of head with antelocular transverse row of four large tubercles and two additional intra-locular tubercles; antennal segment 2 longer than first segment, segment 4 setose; scutellum exposed moderately large; abdominal sterna 2-5 separate.

Type species: Paleoanomala aptenus gen. et sp. nov.

Etymology: Generic name from the Greek "palaios" = old and the Greek "anomalos" = deviating from the general rule, irregular.

Diagnosis: as for type genus (monotypic)

LSID: urn:lsid:zoobank.org:act:9C1D451FD5C4-46DC-81AD-BAD21F72E84C

Type material: Accession number B-He-36 deposited in the Poinar amber collection maintained at Oregon State University.

Etymology: Specific epithet is from the Greek "apten" = unable to fly.

Type locality: Myanmar (Burma), state of Kachin, Noije bum 2001 Summit Site amber mine in the Hukawng Valley, SW of Maingkhwan $\left(26^{\circ} 20^{\prime} \mathrm{N}, 9^{\circ} 36^{\prime} \mathrm{E}\right)$.

Diagnosis: as for genus (by monotypy).

Paleoanomala aptenus gen. et sp. nov.

Description: The specimen is complete (Figs. 210). 


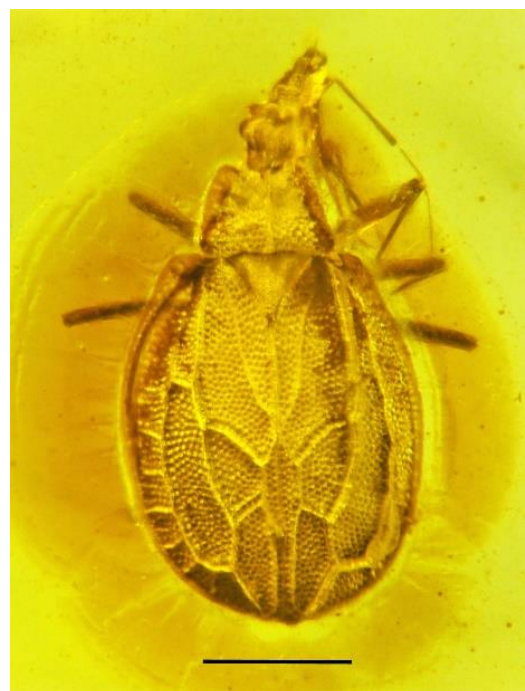

Fig. 2. Dorsal view of Paleoanomala aptenus gen. et sp. nov. in Burmese amber. Scale bar $=0.7 \mathrm{~mm}$.

Head (Fig. 5): Posterior portion of head broader than anterior portion; eyes small, barely protruding laterally, positioned roughly in middle of head; ocelli absent; antennae 4-segmented, second antennal segment longest, $3.4 \mathrm{x}$ as long as first, third, and fourth segments that are much more slender than first two; terminal antennomere distinctly setose, with setae longer than segmental diameter; labium 4-segmented, apex extending to the anterior margin of the metasternum.

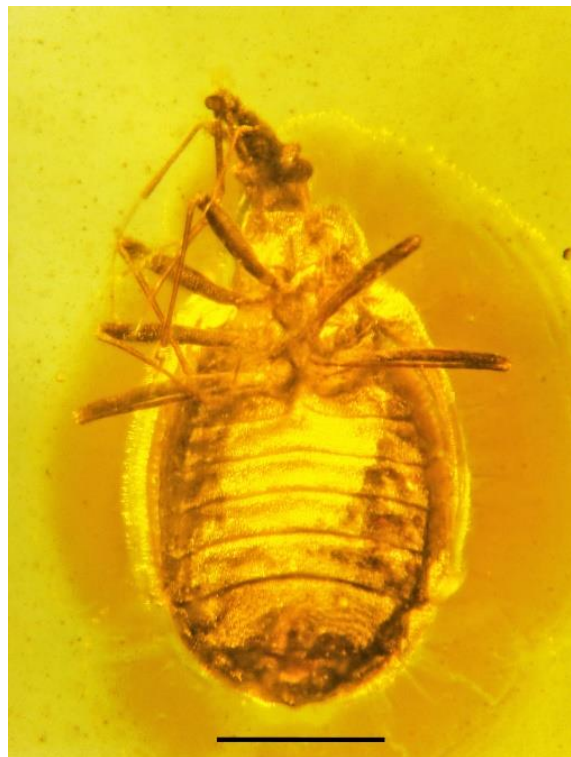

Fig. 3. Ventral view of Paleoanomala aptenus gen. et sp. nov. in Burmese amber. Scale bar $=0.7$ $\mathrm{mm}$.

Thorax (Figs. 2,5,7): Pronotum bilobed, widest posteriorly, with paranota expanded; basal margin of pronotum wider than $\mathrm{V}$-shaped anterior margin, overlapped by scutellum; median carina distinct; lateral carinae somewhat obscured, separating paranotum from disk of pronotum. Pro-, meso- and metasternum separated by transverse sutures. Metanotum fused with first abdominal segment. Legs long and slender, femora and tibiae cylindrical; tarsi twosegmented, claws thin, pulvilli not discernible.

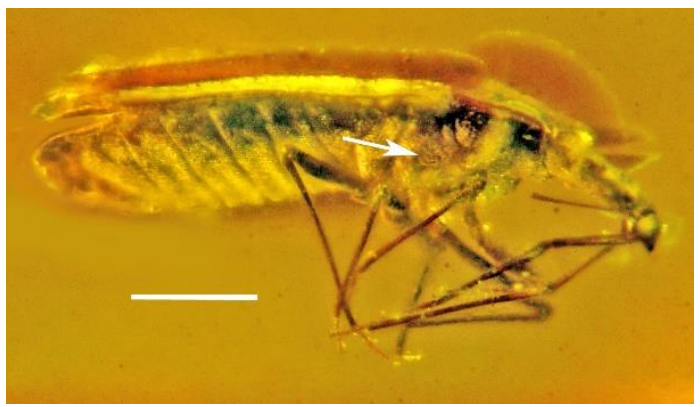

Fig. 4. Lateral view of P. aptenus gen. et sp. nov. in Burmese amber. Arrow shows metathoracic gland opening. Scale bar $=0.7 \mathrm{~mm}$.

Abdomen (Figs. 2-5, 7-10): Disc ovate, covering apex of abdomen, dorsum punctate, reticulately sculptured over entire area, with areoles bordered by large dark tubercles; lateral margins with exposed connexium bearing setose outer cell margins. First five abdominal segments separate, subequal, ranging from 160- $190 \mu \mathrm{m}$ in width. Hypocostal lamina with an indistinct row of small areolae extending only to end of $5^{\text {th }}$ abdominal segment; sternites l-VI separated; sternite VI fused with sternite VII which shows a median and $2(1+1)$ lateral posteriorly directed projections.

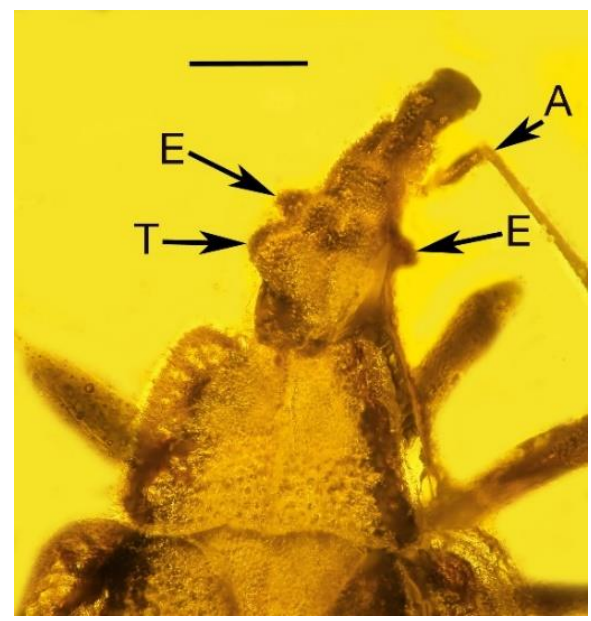

Fig. 5. Eyes (E), antenna (A) and one of four postocular tubercles (T) of Paleoanomala aptenus gen. et sp. nov. in Burmese amber. Scale bar $=222$ $\mu \mathrm{m}$. 


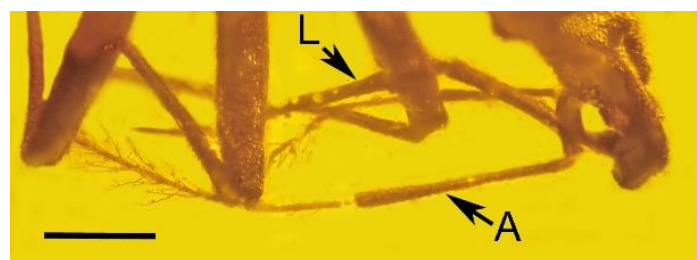

Fig. 6. Labium (L) and antenna (A) of Paleoanomala aptenus gen. et $\mathrm{sp}$. nov. in Burmese amber. Scale bar $=200 \mu \mathrm{m}$.

Measurements: Holotype: Body length from clypeus to apex of abdomen $2.6 \mathrm{~mm}$; head length, $588 \mu \mathrm{m}$; eye diameter, $72 \mu \mathrm{m}$; length of postocular portion eye, $226 \mu \mathrm{m}$; length of anteocular portion $340 \mu \mathrm{m}$; length of antennae 1.1 $\mathrm{mm}$, length of antennal segments I / II / III / IV = $120 / 410 / 230 / 360 \mu \mathrm{m}$, respectively; length of labium segments, I / II / III / IV = 350 / 230/ 230 / $180 \mu \mathrm{m}$, respectively; pronotum length, $420 \mu \mathrm{m}$; pronotum width, $600 \mu \mathrm{m}$; scutellum length, 350 $\mu \mathrm{m}$; scutellum width, $385 \mu \mathrm{m}$; length abdomen, $1.8 \mathrm{~mm}$; width abdomen, $1.5 \mathrm{~mm}$; length profemora, $620 \mu \mathrm{m}$; length protibia, $620 \mu \mathrm{m}$; length mesofemora, $620 \mu \mathrm{m}$; length mesotibia, $570 \mu \mathrm{m}$; length metafemur, $790 \mu \mathrm{m}$; length metatibia, $790 \mu \mathrm{m}$.

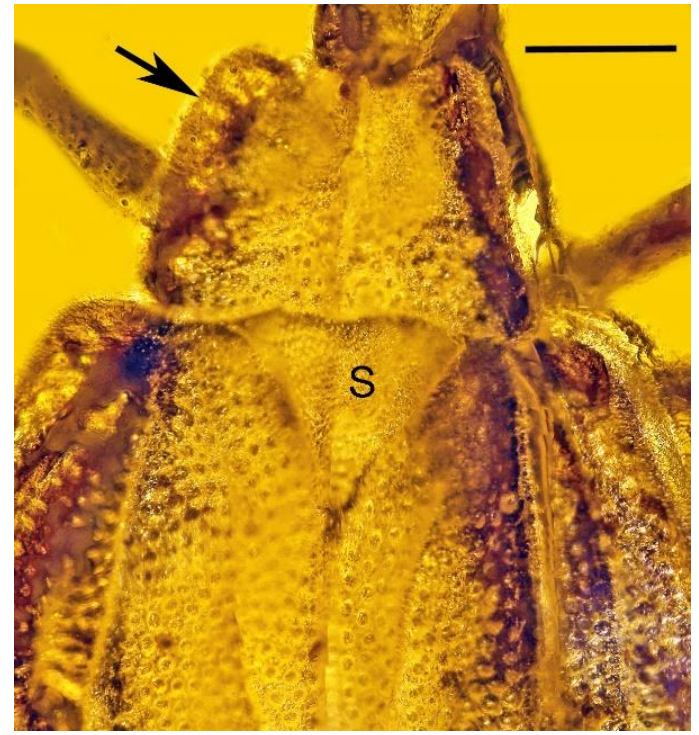

Fig. 7. Dorsal view of pronotum and scutellum (S) of Paleoanomala aptenus gen. et sp. nov. in Burmese amber. Arrow shows paranotum. Scale bar $=230 \mu \mathrm{m}$.

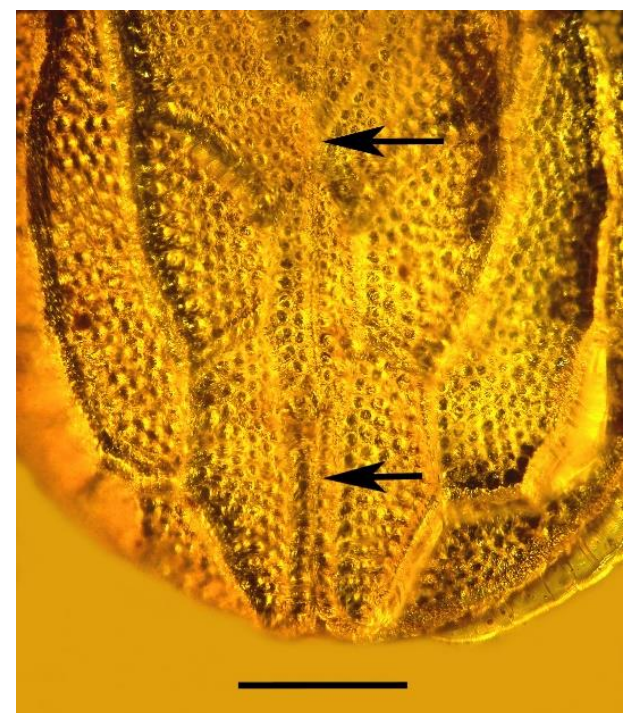

Fig. 8. Dorsal view of abdominal disc of Paleoanomala aptenus gen. et sp. nov. in Burmese amber. Arrows show fused portions of the central suture. Scale bar $=310 \mu \mathrm{m}$.

Comments: While the holotype is placed in the subfamily Tingiometrinae based on the shape of the head, it also possesses some features of the subfamily Vianaididae (Shuh \& Slater, 1995). These include the flightless coleopteroid body, reduced eyes, absent ocelli, moderately large exposed scutellum, and second antennal segment larger than the first. However, abdominal sterna II-V are fused in the Vianaidinae and they are separate in the fossil. Also, the shape of the body and head of the fossil differ from those of the wingless forms of Vianaididae.

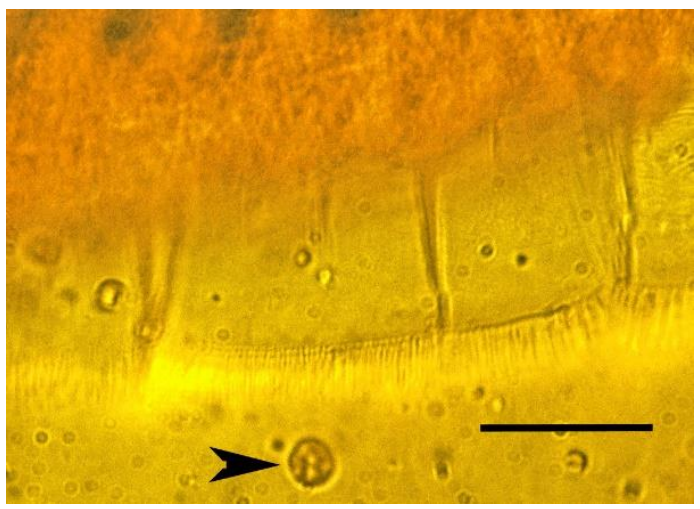

Fig. 9. Connexium with straight, short setae along the border of Paleoanomala aptenus gen. et sp. nov. in Burmese amber. Arrow shows pollen grain. Scale bar $=50 \mu \mathrm{m}$. 


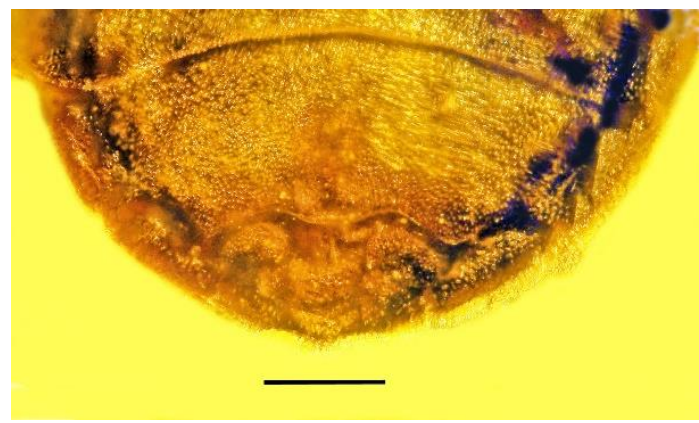

Fig. 10. Terminal abdominal sternites of Paleoanomala aptenus gen. et sp. nov. in Burmese amber. Scale bar $=240 \mu \mathrm{m}$.

\section{Discussion}

Adult Hemiptera exhibit a variety of wing polymorphism (pterygopolymorphism), including macroptery (complete wings), stenoptery (complete but narrowed wings), brachyptery (short, abbreviated wings), microptery (vestigial wings) and aptery (no wings). The partially fused central suture extending the length of the abdominal disc in the fossil indicates that the predecessor of Paleoanomala aptenus gen. et sp. nov. had separate hemielytra. Thus, the fossil represents a transitional stage of a macropterous lineage that is in the process of losing its wings and becoming apterous. The condition of the fossil also could be considered as an extreme form of brachyptery, although the condition of the hind wings, if present at all, is unknown as they are unobservable. Whether macropterous forms of Paleoanomala aptenus gen. et sp. nov. existed concurrently is unknown.

The causes of apterism in Tingidae have been little discussed, even though most members of the Vianaididae, a mainly Neotropical group that appear to be associated with ants, are wingless (Kormilev, 1955; Gross \& Cassis, 1991; Schuh \& Slater, 1995; Golub \& Popov, 2000; Montemayor \& Carpintero, 2007).

It is interesting to compare the condition in Paleoanomala aptenus gen. et sp. nov. with widespread polyphyletic aptery in the Aradidae (Hemiptera). All apterous species of Aradidae are considered to have evolved from macropterous lineages. Some apterous species still retain a scutellum, as in macropterous forms, while in other wingless aradids, wing pads appear in late instars, but disappear in adults (Usinger, 1950). Apterism in aradids and tingids is presumed to arise with the disuse of wings, probably accompanied by shifts to new habitats (Lamarckian concept) (Usinger, 1950).

The present fossil shows that the transition from macroptery to aptery was occurring in tingids by the mid-Cretaceous.

A number of Tingidae have been described from Burmese amber, including Spinitingis ellenbergeri and Burmacader multivenosus (Heiss \& Guilbert, 2013), Tingiometra burmanica (Heiss et al., 2015), Burmacader lativentris (Heiss \& Guilbert, 2018), Paraphatnomacader huarongcheni (Guilbert \& Heiss, 2019a), Tingiphatnoma bispinosa (Guilbert \& Heiss, 2019b), Tingiphatnoma andreneli (Maksoud et al., 2019), Tingiphatnoma suchorskii (Heiss \& Guilbert, 2019), and Tingiometra pankowskii, T. secunda, and T. yuripopovi (Golub \& Heiss, 2020). While quite diverse in morphological features, all of the above specimens have functional wings, which separate them from Paleoanomala aptenus gen. et sp. nov.

Several trinucleate pollen grains are adjacent to the specimen (Fig. 11). These grains closely resemble trinucleate angiosperm pollen depicted by Brewbaker (1967) (Fig. 1). The assumingly vegetative nucleus is the largest of the three. The two small fertilization nuclei are considered to be the egg nucleus and the endosperm nucleus. It is possible that these pollen grains are from flowers of the food plant of Paleoanomala aptenus gen. et sp. nov.

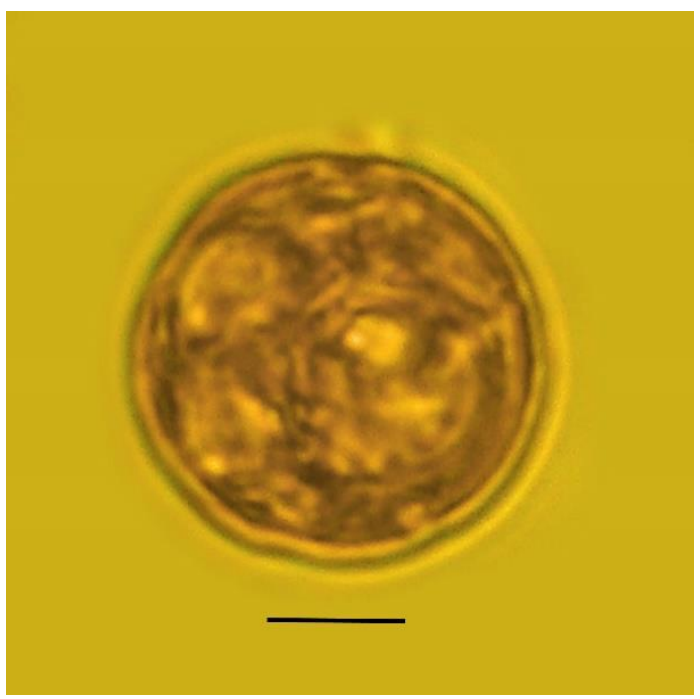

Fig. 11. Detail of the trinucleate pollen grain shown in Fig. 9. Scale bar $=6 \mu \mathrm{m}$. 


\section{Acknowledgements}

The authors thank Ernst Heiss for help with obtaining literature and Ken Chambers for discussions on pollen morphology.

\section{Conflict of interest statement}

The authors declare no conflict of interest.

\section{References}

Brewbaker, J. L. (1967). The distribution and phylogenetic significance of binucleate and trinucleate pollen grains in the angiosperms. American Journal of Botany, 54(9), 10691083. $\quad$ https://doi.org/10.1002/j.15372197.1967.tb10735.x

Comstock, J. H. (1950). An Introduction to Entomology ( (th $^{\text {th }}$ ed.). Comstock Publishing Company.

Cruickshank, R. D., \& Ko, K. (2003). Geology of an amber locality in the Hukawng Valley, northern Myanmar. Journal of asian earth Sciences, 21(5), 441-455. https://doi.org/10.1016/S13679120(02)00044-5

Golub, V. B., \& Popov, Y. A. (2000). A remarkable fossil lace bug from Upper Cretaceous New Jersey amber (Heteroptera: Tingoidea, Vianaididae), with some phylogenetic commentary. In D. Grimaldi (Ed.), Studies on Fossils in Amber, with Particular References to the Cretaceous of New Jersey (pp. 231-239). Backhuys Publishers.

Golub, V. B., \& Heiss, E. (2020). Three new species of the lacebug genus Tingiometra from Cretaceous Burmese amber (Hemiptera: Heteroptera: Tingidae: Tingiometrinae). Zootaxa, 4767(4), 531-542. https://doi.org/10.11646/zootaxa.4767.4.3

Gross, C. F., \& Cassis, G. (1991). Superfamily Tingoidea, In: The Insects of Australia: A Textbook for Students and Research Workers (pp. 493-494). Cornell University Press.

Guilbert, E., \& Heiss, E. (2019a). New lacebugs (Hemiptera: Heteroptera: Tingidae) from Upper Cretaceous Burmese amber. Cretaceous Research, 94, 72-79. https://doi.org/10.1016/j.cretres.2018.10.024

Guilbert, E., \& Heiss, E. (2019b). New species of Tingiphatnoma from Cretaceous Burmese amber (Heteroptera, Tingidae). Palaeoentomology, 2, 340-344. https://doi.org/10.11646/palaeoentomology. 2.4 .7

Heiss, E., \& Guilbert, E. (2013). Two new genera and species of Tingidae from Cretaceous amber from Myanmar (Burma) (Hemiptera: Heteroptera). Zootaxa, 3736(4), 379-386. https://doi.org/10.11646/zootaxa.3736.4.5

Heiss, E., \& Guilbert, E. (2018). A new species of Tingidae from Cretaceous amber from Myanmar (Hemiptera: Heteroptera). Zootaxa, 4457(2), 339-345. https://doi.org/10.11646/zootaxa.4457.2.10

Heiss, E., \& Guilbert, E. (2019). New species of Tingiphatnoma from Cretaceous Burmese amber (Heteroptera, Tingidae). Palaeoentomology, 2(4), 340-344. http://dx.doi.org/10.11646/palaeoentomolog y.2.4.7

Heiss, E., Golub, V. B., \& Popov, Y. A. (2015). A new subfamily, genus and species of Tingidae (Hemiptera: Heteroptera) from Burmese amber. Zeitschrift der Arbeitsgemeinschaft Österreichischer Entomologen, 67, 1-9.

Kormilev, N. A. (1955). A new myrmecophile family of Hemiptera from the delta of Rio Parana, Argentina. Revista Ecuatoriana de Entomología y Parasitología, 2, 465-477.

Laporte, F.L. de (1833). Essai d'une classification systématique de l'ordre des Hémiptères (Hémiptères Hétéroptères, Latr.). Magasin de Zoologie, 2, 1-88.

Maksoud, S., Azar, D., \& Huang, D. (2019). Tingiphatnoma andreneli sp. nov., a new tingid bug from the mid-Cretaceous Burmese amber (Heteroptera, Tingidae). Palaeoentomology, 2(6), 576-580. http://dx.doi.org/10.11646/palaeoentomolog y.2.6.6

Montemayor, S. I., \& Carpintero, D. L. (2007). A new macropterous genus with a new species of Vianaididae (Heteroptera, Tingoidea, Vianaididae) from Peru. Studies on Neotropical Fauna and Environment, 42(2), 133-136. https://doi.org/10.1080/01650520600997611

Poinar Jr., G. (2019). A Naturalist's Guide to Plant Communities of Pacific Northwest Dune Forests and Wetlands. Texas, U.S.A.: BRIT Press.

Poinar Jr, G. O., Lambert, G. J. B., \& Wu Y. (2007). Araucarian source of fossiliferous Burmese amber: spectroscopic and anatomical evidence. Journal of the Botanical Research Institute of Texas, 1(1), 449-455. 
Schuh, R. T., \& Slater, J. A. (1995). True Bugs of Research, 37, 155-163. the World (Hemiptera: Heteroptera). Cornell University Press.

Shi, G., Grimaldi, D. A., Harlow, G. E., Wang, J., Wang, J., Yang, M., Lei, W, Li, Q, \& Li, X. (2012). Age constraint on Burmese amber based on $\mathrm{U}-\mathrm{Pb}$ dating of zircons. Cretaceous

https://doi.org/10.1016/i.cretres.2012.03.014

Usinger, R. L. (1950). The origin and distribution of apterous Aradidae. Proceedings of the Eighth International Congress of Entomology, pp. 174-179.

cc) $\bigoplus$ Publisher's note: Eurasia Academic Publishing remains neutral with regard to jurisdictional claims in published maps and institutional affiliations.

Open Access This article is licensed under a Creative Commons Attribution-NoDerivatives 4.0 International (CC BYND 4.0) licence, which permits copy and redistribute the material in any medium or format for any purpose, even commercially. The licensor cannot revoke these freedoms as long as you follow the licence terms. Under the following terms you must give appropriate credit, provide a link to the license, and indicate if changes were made. You may do so in any reasonable manner, but not in any way that suggests the licensor endorsed you or your use. If you remix, transform, or build upon the material, you may not distribute the modified material.

To view a copy of this license, visit https://creativecommons.org/licenses/by-nd/4.0/. 